\title{
Violence against Women - A Challenge to the Supreme Court
}

\section{Citation}

Martha L. Minow, Violence Against Women - A Challenge to the Supreme Court, 341 N. Eng. J. Med. 1927 (1999).

\section{Published Version}

http://www.nejm.org/doi/full/10.1056/NEJM199912163412511

\section{Permanent link}

http://nrs.harvard.edu/urn-3:HUL.InstRepos:12939469

\section{Terms of Use}

This article was downloaded from Harvard University's DASH repository, and is made available under the terms and conditions applicable to Other Posted Material, as set forth at http:// nrs.harvard.edu/urn-3:HUL.InstRepos:dash.current.terms-of-use\#LAA

\section{Share Your Story}

The Harvard community has made this article openly available.

Please share how this access benefits you. Submit a story.

Accessibility 


\section{ViOLENCE Against WOMEN - A Challenge to THe Supreme Court}

$\mathrm{T}_{\mathrm{r}}$ HIS issue of the Journal includes two reports on risk factors for violent injuries to women. The findings of Kyriacou et al. ${ }^{1}$ and Grisso et al., ${ }^{2}$ from case-control studies in hospital emergency rooms, are not surprising. But the public-policy implications deserve renewed attention as the Supreme Court considers whether to strike down the 1994 Violence against Women Act as unconstitutional.

Kyriacou et al. report that the chief risk factors for injuries to women as a result of domestic violence are alcohol or drug abuse by male partners and having a partner who is unemployed or intermittently employed. Grisso et al. found that partners who abuse women are much more likely than nonabusive partners to use cocaine. In addition, women in lowincome neighborhoods have an even greater risk of being injured by neighbors, acquaintances, and friends than by their partners or by strangers. Perhaps the most striking insights come from reading the two reports together: Grisso et al. found that high proportions of both intentionally injured women (48 percent) and women in the control group (51 percent) reported having had an abusive partner in the past, and Kyriacou et al. found that having a former partner was the relationship variable with the strongest association with injury as a result of domestic violence. Other research also suggests that the most dangerous time for any abused woman is when she is threatening to leave or has left the relationship. ${ }^{3}$ Trudy Gregorie, director of training at the National Center for Victims of Crime, explains that, "that's when the abuser realizes that they have lost control over the individual and ... losing that power can cause the abuse to go from verbal to physical, or from less serious to more serious violence." 4

The obvious public response is to ensure that health care providers, police, clergy, and even teachers are equipped to help adolescent girls and women find psychological, legal, and economic assistance so that they can leave abusive partners in safety and remain safe over the long term. As daunting as the task may sound, many communities have already taken big steps toward realizing this goal. In Concord, Massachusetts, the Domestic Violence Victim Assistance Program coordinates efforts by volunteers and police to provide victims with confidential support and safe options; volunteers wear beepers, and police, in the light of new laws, are now more likely to arrest abusive partners. ${ }^{5}$ Hospitals in San Diego, California, train staff members and physicians to identify and deal with victims of domestic violence and provide advocacy services and counseling for battered women. ${ }^{6}$ In Dallas, the Violence Intervention and
Prevention Center helps victims change their lifestyles to avoid future violence and offers treatment to clients of shelters for battered women; a newly launched "safe campus" facility in Dallas provides a 100-bed shelter, transitional housing, and job and computer training to these women, as well as day care, schooling, and therapy for their children. ${ }^{7} \mathrm{~A}$ Santa Clara, California, hospital trains nurses to gather evidence to help prosecutors build a case against perpetrators of domestic violence, and advocates arrange to take victims to shelters and to court. ${ }^{8}$

Involvement by medical personnel can backfire for the women who are at risk for domestic violence. One emergency room physician recently told me that she had made an unorthodox decision after watching a husband explode while reading his wife's chart and finding a reference to suspected abuse. The physician decided to keep two sets of charts: one in a locked file in which she would note suspected instances of abuse and one in an unlocked file in which she would not record such instances. The physician explained that a controlling partner could manipulate the patient's access to the chart in order to monitor and constrain her efforts to get help.

Despite the difficulties involved, including physicians and nurses in the struggle against domestic violence is a crucial step. So are efforts to increase the access of victims of domestic violence to court so that they can obtain civil-protection orders, which will trigger jail sanctions for those who violate these orders. Providing advocates, extending court hours into the evening, and linking courts to health and socialservice agencies can increase the likelihood that these women will seek and gain safety. Many women also fear losing custody of their children because socialservice agencies and judges have started to fault women for failing to protect their children from witnessing violence in the home. ${ }^{9}$ Assuring women that they will not lose their children because of the violence of the men in their lives is not only right, but also necessary to ensure that such women are not deterred from reporting episodes of domestic violence. At least as crucial are efforts to move beyond the short-term solutions provided by shelters to the creation of housing and jobs programs to alleviate the economic worries that keep these women in abusive situations.

But perhaps nothing would constrain violence against women more than crystal-clear public and cultural messages that such behavior will not be tolerated. On this score, the United States is in a crucial period of transition. Until recently, police departments and courts failed to treat assaults against women by their partners as seriously as they treated other forms of assault. Indeed, throughout the 19th century, state laws and cultural practices effectively condoned family violence and a husband's prerogative to "discipline" his wife. Even after the formal laws changed, police and prosecutors often refused to in- 
tervene in such matters and at best tried to mediate the disputes quietly, without public sanctions.

A 1991 Senate report concluded that public reactions to assaults against men differ markedly from reactions to assaults against women ${ }^{10}$ :

Typically, we do not ask whether the victim of a barroom brawl is a real victim; we do not comment that the victim deserved to be hit; we do not inquire whether there was resistance or whether the victim said "no" persistently enough; we do not believe that the crime may have been fabricated altogether. Until the stereotypes upon which these scenarios are built seem as foreign for the victims of rape and domestic violence as they do for the victims of barroom brawls, our criminal justice system will pose barriers for women in society it does not pose for others in our society.

Toward that end, in 1994 Congress adopted the Violence against Women Act. The resulting grants have so far distributed over $\$ 1.6$ billion to states, local governments, and Indian tribes to generate vital financial and symbolic support for both law-enforcement agencies and services to assist victims of domestic violence. The act set up a panel to promote research on domestic violence, and Kyriacou et al. have explicitly taken up the panel's challenge to improve understanding of the risk factors for domestic violence. The federal statute also creates a civil-rights remedy: it permits victims to bring federal lawsuits against perpetrators of sexually motivated violence and thereby reinforces state and local laws without supplanting them. For the first time in the nation's history, violence against women is being condemned at the highest levels and resources are available to do something about it locally.

Yet, the Violence against Women Act faces constitutional challenge. Indeed, most savvy court watchers predict that the Supreme Court will strike it down during the current term. The technical arguments may not interest nonlawyers, but they should. The first question before the Court is whether Congress has the power to adopt such a law as part of its authority to regulate interstate commerce. Congress claims that it does. Congress announced findings that violence against women impairs women's abilities to pursue employment and to show up at work, hurts businesses as a result of increased absenteeism, increases employee turnover and health care expenses, and affects national health care costs. Challengers claim that these effects on interstate commerce are either too indirect or too insubstantial to fall within the purview of Congress.

The second question before the Supreme Court is whether the power of Congress to enforce the 14th Amendment's guarantee of equal protection encompasses the act. This power, established after the Civil War to ensure that the states did not refuse to enforce the laws to protect blacks as well as whites, surely is also meant to ensure that the states do not refuse to enforce the laws to protect women as well as men. Again, Congress produced extensive evidence of a widespread bias against women in state court systems. If the Supreme Court accepts the challenges, it may strike down not only the civil-rights remedy but also the entire Violence against Women Act, including its support for local law-enforcement agencies and health and social services.

Over the past several years, the Supreme Court has actively approved sharp constraints on the power of Congress, especially in areas conventionally associated with states' power. Matters affecting women have traditionally been treated as quintessentially areas of state, rather than federal, concern. But equal protection under the law is a federal concern, as are the regulation of drugs and alcohol and poverty and unemployment stemming from national, and indeed, global, economic forces. Each of these is related to the issue of violence against women. As Grisso et al. make clear, women in low-income areas face severe risks of violence in their neighborhoods as well as in their homes. In 87 percent of the episodes involving violent acts committed by persons other than the women's partners there were witnesses to the event. Strengthening community policing and public condemnation of violence must be priorities if this pattern is to change. Someone indifferent to global economic trends and national economic policy may suggest that these, too, are exclusively areas of state and local concern, but national criminal justice, labor, housing, and urban policies can be used to reject this view.

These points can be summarized in practical terms. First, domestic violence is pervasive, and a woman remains at risk even after she has left an abusive partner. ${ }^{11,12}$ Second, the time at which women most need protection from domestic violence is immediately before and after they leave their abusive partners. Third, until recently, long-standing legal and cultural practices led to a refusal to help women escape from domestic violence. Fourth, in some communities, women face an even higher risk of being injured by acquaintances than by partners. Fifth, the likelihood of violent injuries among women in their homes - and in their neighborhoods - is highly related to alcohol and drug abuse by their partners or other persons and to the poverty and economic insecurity of those committing the violent acts. Furthermore, these patterns of violence have demonstrable economic consequences and reflect long-standing failures to ensure women equal protection under the law. Finally, sufficient political will has been mustered to bring financial and symbolic resources to address these problems. The nine members of the Supreme Court should not turn back the tide.

Martha Minow, J.D. Harvard Law School Cambridge, MA 02138 


\section{REFERENCES}

1. Kyriacou DN, Anglin D, Taliaferro E, et al. Risk factors for injury to women from domestic violence. N Engl J Med 1999;341:1892-

2. Grisso JA, Schwarz DF, Hirschinger N, et al. Violent injuries among women in an urban area. N Engl J Med 1999;341:1899-905.

3. Mahoney MR. Legal images of battered women: redefining the issue of separation. Mich L Rev 1991;90:1-94.

4. Masters BA, Smith L. In some domestic cases, legal system falls short. Washington Post. January 27, 1999:B1.

5. Hinkle A. New efforts help fight domestic violence; area organizations, police work together. Boston Globe. June 13, 1999:1.

6. Duerksen S. Health foundation gives $\$ 1.9$ million to local program. San Diego Union-Tribune. March 5, 1999:B-3.

7. Reaves G, Giffin L. Out of darkness, toward the light; agencies' coop- eration cited in Dallas gains on domestic abuse. Dallas Morning News. December 13, 1998:1A.

8. Pimentel B, Gaura MA. Hospital's new way to fight abuse: staff will ask patients about domestic violence. San Francisco Chronicle. September 1, 1998:A13.

9. Miccio GK. A reasonable battered mother? Redefining, reconstructing, and recreating the battered mother in child protective hearings. Harv

Womens L J 1999;22:89-121.

10. Senate report no. 102-197. Report on the Violence against Women Act of 1991 at 34 (October 29, 1991)

11. Giordano BP. Use your power to be an advocate for women's health. AORN J 1997;66:219, 222.

12. Shea CA, Mahoney M, Lacey JM. Breaking through the barriers to domestic violence intervention. Am J Nurs 1997;97:26-33.

(C)1999, Massachusetts Medical Society. 